\title{
Moderation Effect of Education to the Effect of Market Orientation and Technology Orientation on Entrepreneurship Orientation at Small-and-Medium Enterprises (SMEs) in East Java, Indonesia
}

\author{
Salim Al Idrus \\ Department of Management, State Islam University of Maulana Malik Ibrahim Malang, \\ Malang, 65144, Indonesia
}

\begin{abstract}
The research was aimed to uncover the effect of market orientation and technology orientation on entrepreneurship orientation with education as a moderator variable. This research used the quantitative approach and the causal relationship between variables was investigated through Structural Equation Modeling-Partial Least Squares (SEMPLS). The research population included Small-and-Medium Enterprises (SMEs) in East Java, Indonesia, and 168 SMEs were selected as the sample. The findings of the research revealed that education attainment levels could reduce the effect of market orientation on entrepreneurship orientation and could increase the effect of technology orientation on entrepreneurship orientation. Based on the findings, it is recommended that SMEs in East Java must improve their entrepreneurship orientation by intensifying the variation of the market's supply and demand, upgrading technology, and hiring workers who have the required educational background, and then training them on the latest technology.

Keywords: Education, entrepreneurship orientation, market orientation, small-and-medium enterprises of Indonesia, technology orientation
\end{abstract}

ARTICLE INFO

Article history:

Received: 30 October 2019

Accepted: 06 July 2020

Published: 25 December 2020

DOI: https://doi.org/10.47836/pjssh.28.4.12

E-mail address:

salim.alaydrus@manajemen.uin-malang.ac.id

\section{INTRODUCTION}

One of the business sectors with a strong contribution to the growth of the Indonesian economy is the Small-and-Medium Enterprises (SMEs) sector (Anton et al., 2015). Small-and-Medium Enterprises had contributed to $60.3 \%$ of the growth of the Indonesian Gross Domestic Product (GDP) in 2018. The problem is that most 
Indonesian SMEs do not understand the importance of entrepreneurship values (Octavia \& Ali, 2017; Rahyuda et al., 2017). Indonesian SMEs need knowledge of entrepreneurship values, such as innovation, creativity, and risk-taking, to improve their business performance (Abdilahi \& Hassan, 2017; Heslina et al., 2016; Wambugu et al., 2015).

Low entrepreneurship orientation among SMEs is caused by the decline of their market orientation and technology orientation (Hidayat et al., 2016; Hussain et al., 2016). It is not surprising to see SMEs are always faced with difficulty when competing with larger business units because their marketing still focuses on the domestic market and low-income consumers (Anton et al., 2015; Octavia \& Ali, 2017). The quality of SMEs' products is not competitive because the quality of raw materials, machines, and technologies are still poor, and the consequences of this are that they are in a less favorable position. Consumer trust declines and product distribution becomes stagnant (Hadiyati, 2015; Omar \& Anas, 2014). All these factors force SMEs to have low market orientation, which then leads them into difficulties in market penetration and in having a larger consumer share.

Besides low market orientation, Indonesian SMEs are less competent in technology capability and business management (Anton et al., 2015; Astutie \& Fanani, 2016; Hadiyati, 2015). It is not peculiar to see SMEs refraining from adopting new technology because the adoption itself is always problematic to them
(Munizu et al., 2016). As a consequence, it is hard for SMEs to manage their resources optimally, and this, in turn, results in a bad impact; it leads to low productivity and disrupted product innovation (Ling, 2017; Pustovrh et al., 2017).

Apart from both market orientation and technology orientation, which indeed are undesirably low, the entrepreneurship orientation of SMEs is also affected by education (Nwachukwu et al., 2017; Pett \& Wolff, 2016). The education system plays a vital role in developing entrepreneurship orientation because education helps individuals to develop their capabilities on innovation, creativity, and in measuring difficulties (Nga \& Shamuganathan, 2010). Besides, education has had a significant moderation effect on entrepreneurs because it enables them to develop capabilities in conducting market analysis or in using technology. This would increase their intellectual capability. Education has a moderation effect on the attitudes of entrepreneurs (Bae et al., 2014; Entrialgo \& Iglesias, 2016; Souitaris et al., 2007) because currently, educational institutions are required to improve the entrepreneurship orientation of their educated participants by teaching them on technology, financial science, and communication skills because all of these are considered important for success in business (Fayolle \& Gailly, 2015; Nabi et al., 2015; Piperopoulos \& Dimov, 2015).

Patricia and Silangen (2016) suggested that education indirectly affected someone's desire to start a business, especially if the 
knowledge that was needed was related to the field of entrepreneurship (Buana et al., 2017; Ertuna \& Gurel, 2011; Nabi et al., 2017). Through policies issued by the government in the form of the improvement of technological infrastructure and the provisioning of various types of facilities that support entrepreneurship, the education level, therefore, is meant to enable SMEs to increase their productivity (Chienwattanasook \& Jermsittiparsert, 2019; Entrialgo \& Iglesias, 2016; Shah et al., 2020).

Reports from the field indicate that Indonesian workers in SMEs have low education levels. Indonesian SMEs tend to be labor-intensive, and therefore, young and lowly educated workers are preferred for employment (Anton et al., 2015). Berrill et al. (2018) indicated that education did not have a moderation effect on entrepreneurship orientation because someone who was highly educated prefered to work in companies with high salaries rather than being entrepreneurs. In the era of globalization, the presence of multinational companies in developing countries has attracted a significant portion of the workforce through a variety of offerings. This indicates that the moderation effect of education will negatively impact the entrepreneurship orientation of the community (Bae et al., 2014; Danakol et al., 2017; Kunday \& Çakir, 2014).

By taking into consideration the aforesaid discussion, the author makes the early deduction that some factors have been affecting the entrepreneurship orientation of SMEs in Indonesia, and that the factors observed in this research are market orientation, technology orientation, and education. Therefore, the objective of this research was to uncover the effect of market orientation and technology orientation on entrepreneurship orientation of SMEs in Indonesia with education as a moderator variable.

\section{MATERIALS AND METHODS}

\section{Market Orientation}

Market orientation is a process to anticipate and learn what customer demands will be at present and in the future. This process is done by disseminating market intelligence to the internal parts of the organization and also by being responsive to market intelligence received from others (Dursun \& Kilic, 2017). Small-and-Medium Enterprises with market orientation are those that can understand customer demands, and this understanding shall help them to offer solutions concerning how to satisfy customer demands in better ways than their competitors (Oluwatoyin et al., 2018). Market-oriented Small-andMedium Enterprises will emphasize their abilities in producing excellent consumer value, in changing consumer satisfaction into consumer loyalty, in anticipating competitors' moves, and also in considering marketing as an investment (Dursun \& Kilic, 2017).

Market orientation is a fundamental aspect of marketing that can contribute to SMEs' business performance (Al Asheq \& Hossain, 2019). Market orientation involves such activities as disseminating 
market intelligence to the internal parts of the organization, being responsive to market intelligence of competitors, and learning about the market (Hinson et al., 2017). Therefore, market-oriented SMEs are those with greater capability to fulfill consumer demands. Such enterprises have a greater opportunity to see their performance increased.

\section{Technology Orientation}

Technology orientation is defined as a predisposition of firms/enterprises to introduce or use their new technology, new product, or innovation based on customer value. Therefore, the long-term success of an organization shall depend on innovation and problem-solution that involve new technology (Obeidat, 2016). Technology orientation comprises many activities, such as being proactive in developing new ideas and technology that concern new products, making integration with new technology, and using technology effectively in developing new products (Acar \& Özşahin, 2017).

Small-and-Medium Enterprises with technology orientation are those that have excellent technology and also have the capability to produce more innovative products (Acar \& Özşahin, 2017). Technology oriented SMEs have more leverage than their competitors. They have a stronger network with other providers of technology, better knowledge about technology, and the ability to design new products with current technology (Tarighi et al., 2017). Technology excellence will determine whether products are acceptable or not in the market because consumers may only seek products with good quality, and if the market considers the products acceptable, then Small-and-Medium Enterprises will find their performances increased.

\section{Education}

It is necessary for Small-and-Medium Enterprises to improve human resource quality through knowledge. Indeed, knowledge is a cognitive capacity to recognize, understand, realize, and solve problems, and one way to obtain this knowledge is through education (Sembiring, 2016). Education is closely related to organizational learning in SMEs. Organizational learning is a set of organizational behavior that affects the ways the organization in using knowledge to learn about the business environment and to respond to environmental demand. It is already said by Buana et al. (2017) that education had a significant role in developing someone's ability to become an entrepreneur, because, basically, many universities prepared students directly into becoming entrepreneurs. Undergraduates develop innovative capacity and creativity while undergoing their studies (Patricia \& Silangen, 2016).

Education level affects entrepreneurs' skills in analyzing business opportunities and managing resources. Even, individuals with high education consider becoming entrepreneurs as it seems to be a more attractive choice compared to working as an employee (Berrill et al., 2018; Bosma \& 
Schutjens, 2011). Peterman and Kennedy (2003) stated that although education was proven to have a significant role in entrepreneurship orientation, in-depth research was still needed concerning the moderation effect of education on entrepreneurship orientation.

\section{Entrepreneurship Orientation}

Entrepreneurship orientation is a strategic orientation to utilize entrepreneurship values that help the firm/enterprise in standing above competitors and to take benefits from exploiting new opportunities and innovation in an uncertain environment (Obeidat, 2016). Entrepreneurship orientation is defined as an attitude to pursue new opportunities through a combination of internal resources supported by a variety of strategies, which among others is showing innovative, proactive, and risk-taking postures (Charupongsopon \& Puriwat, 2017).

Small-and-Medium Enterprises with entrepreneurship orientation are those with the courage to show themselves as business units with the capability to attain excellent performance through innovation, proactivity, and risk-taking, and with support from top management (Obeidat, 2016). Entrepreneurship-oriented SMEs that adhere to this are those with better performance (Haliq et al., 2018).

\section{Market Orientation, Education, and Entrepreneurship Orientation}

Market orientation can be regarded as a predisposition of SMEs to implement marketing concepts in order to find new consumers and maintain the existing consumers (Amfo et al., 2018; $\mathrm{Na}$ et al., 2019). To own market orientation, Small-and-Medium Enterprises need to understand market demands and implement business strategies to operate their business (Ismail \& Alam, 2019). Besides, Small-andMedium Enterprises must put attention to entrepreneurship values such as business innovation, risk-taking, and competing ability (Khaleel et al., 2017; Oni et al., 2019).

Entrepreneurship values are needed by SMEs to help them in targeting the market and if a certain market is successfully targeted, the SME becomes more marketoriented (Mugambi \& Karugu, 2017). Small-and-Medium Enterprises with entrepreneurship orientation tend to respond to consumer demands better than those without entrepreneurship orientation (Amin et al., 2016). Entrepreneurship capability depends on knowledge, and education is one factor supporting the attainment of entrepreneurship orientation (Mutlutürk, 2018)

Given all statements above, the two following hypotheses are formulated:

$\mathrm{H}_{1}$ : There is a positive and significant effect of market orientation on the entrepreneurship orientation of SMEs in East Java.

$\mathrm{H}_{2}$ : Education moderates the effect of market orientation on entrepreneurship orientation of SMEs in East Java. 


\section{Technology Orientation, Education, and Entrepreneurship Orientation}

Small-and-Medium Enterprises need to use innovation to provide new products (Ismanu \& Kusmintarti, 2019). Product innovation is only possible if SMEs use up-to-date technology (Aksoy, 2017; Diaw \& Asare, 2018; Ungerman et al., 2018). Small-andMedium Enterprises that have up-to-date technology and apply this technology to respond to consumer demands are those that have technology orientation (Ali et al., 2016; Lo et al., 2016).

Technology orientation helps to internalize entrepreneurship values, such as innovation and business strategy, into Small-and-Medium Enterprises (Ibrahim et al., 2017). In applying new technology and improving entrepreneurship orientation, Small-and-Medium Enterprises must have innovation capability and technological friendly procedure, and both factors can improve the SME's productivity (Asim \& Sorooshian, 2019; Tseng et al, 2019). Knowledge about new technology and skill to use it are two factors needed to attain entrepreneurship orientation (Madu, 2016).

Taking into account all explanations in this section, the following hypotheses are developed:

$\mathrm{H}_{3}$ :There is a positive and significant effect of technology orientation on the entrepreneurship orientation of SMEs in East Java.

$\boldsymbol{H}_{4}:$ Education moderates the effect of technology orientation on the entrepreneurship orientation of SMEs in East Java.

\section{Population and Sample}

The research was done on the managers of Small-and-Medium Enterprises in East Java. The total number of SMEs observed in this research was 757,090, and all were obtained from the list of SMEs at the East Java Cooperative Office. Inclusion criteria used to sort SMEs were: annual turnover of 2 billion rupiahs, assets of 500 million rupiahs, and minimum age of 10 years. Based on these criteria, the research population was targeted at 288 managers. The sampling technique was purposive sampling. The sample consisted of 168 SME managers, and this was obtained after applying this technique to the population. The sample size was determined by the Taro Yamane Formula (Yamane, 1967):

$$
\mathrm{n}=\frac{\mathrm{N}}{\mathrm{Nd}^{2}+1}=\frac{288}{288 \times 0.05^{2}+1}=167.44=168
$$

In this research, there were 288 questionnaires distributed. The number of questionnaires returned was 195. The number of the questionnaire completed was 168 , while that was not completed by respondents was 27 . Therefore, the response rate was $86.15 \%$.

\section{Variable and Measurement Instrument}

Variables to be analyzed are latent variables, also known as a construct or unobserved variables, and indicator variables such as observed variables of each latent variable. The latent variable consists of exogenous and endogenous latent variables. The exogenous latent variables in this research 
are (1) Market Orientation (MO); (2) Technology Orientation (TO); and (3) Education (E), while the endogenous latent variable is Entrepreneurship Orientation (EO). Data of all four variables were collected through questionnaires. The details are given as follows:

1. Entrepreneurship Orientation (EO) is explained by: (a) new product innovation and strategy to use it (EO1); (b) proactivity in business (EO2); and (c) risk-taking (EO3).

2. Technology Orientation (TO) is indicated by technology novelty (TO1).

3. Education (E) is represented by education level (E1).

4. Market Orientation (MO) is explained by (a) activity to collect market intelligence from customers (MO1); (b) activity to draw market intelligence from competitors (MO2); (c) activity to disseminate market intelligence to internal elements (MO3); (d) activity to follow market development (MO4); (e) responsiveness to customer complaints (MO5); and (f) responsiveness to what competitors do (MO6).

The research was designed to use the quantitative approach. Structural Equation Modelling Partial Least Squares (SEM PLS) was utilized to understand the causal relationship of research variables. The approach of SEM PLS run the empirical simulation by multiplying the score of each indicator in the observed variables, and also by constructing the possible interaction involving exogenous variables and moderator variables. SEM PLS can directly measure the reflection of the constructed relationship between exogenous variables and moderator variables (Becker et al., 2018; Shah et al., 2020). The hypothesis model is displayed in Figure 1.

Data analysis and hypothesis testing were conducted with Structural Equation Modelling Partial Least Squares (SEM PLS), and the operation was supported by SmartPLS version 3.2.7. The relationship between exogenous and endogenous latent variables was also tested with SEM PLS.

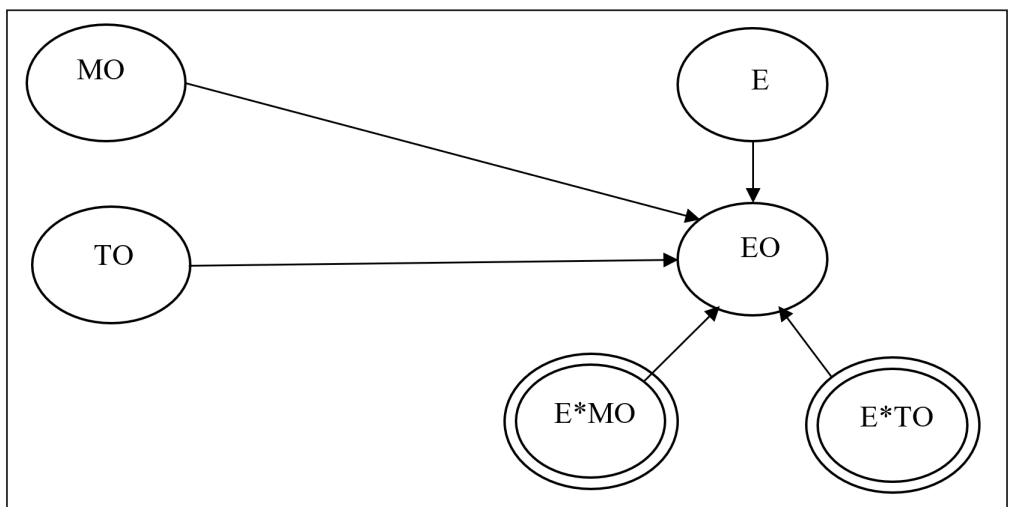

Figure 1. Hypothesis model 


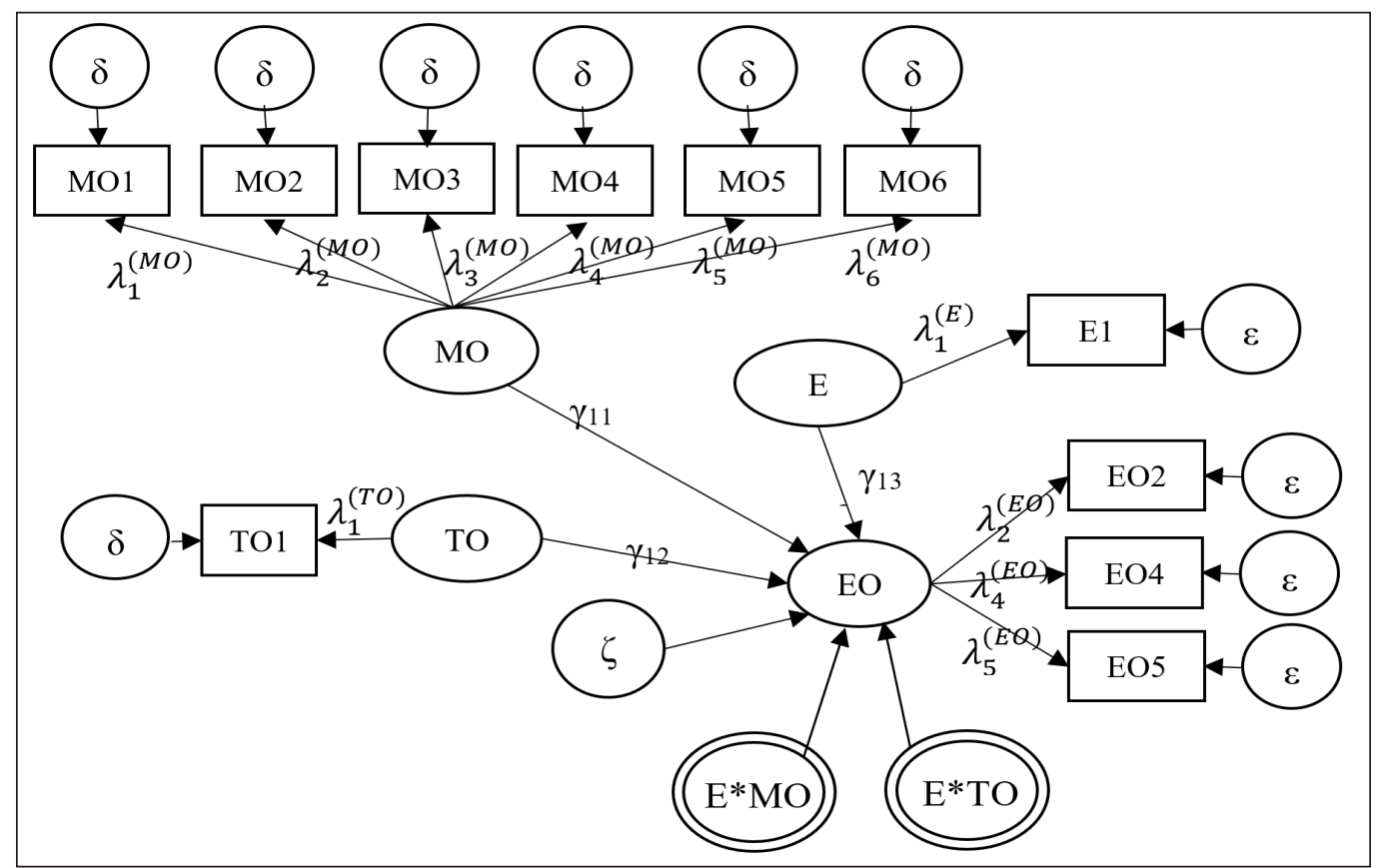

Figure 2. Research model

The research model is made of four latent variables, and each of them has its own explanatory indicators. Figure 2 displays this research model.

\section{RESULTS AND DISCUSSION}

\section{Goodness-of-Fit Test on Outer Model}

The goodness-of-fit test was conducted on the outer model by carrying out a test against convergent validity (based on factor loading rate and AVE rate), discriminant validity (based on cross loading rate), and reliability (based on composite reliability rate). Table 1 describes the factor loading rate of each indicator of latent variables.

The AVE rate of each latent variable is presented in Table 2.

Based on items shown in Table 1 and 2, all factor loading rates are higher than
0.7, while all AVE rates are more than 0.5. Referring to the principle stated by Hair et al. (2014), therefore, the outer model is fulfilling the condition of convergent validity.

Table 3 shows cross loading rate of each indicator on latent variables.

As it is revealed in Table 3, at least, in every relationship of indicator and latent variables, each indicator has the highest cross loading rate compared to the cross-loading rate of each latent variable. Based on the principle stated by Hair et al. (2014), it can be said that the outer model has successfully fulfilled the condition of discriminant validity. The description of the composite reliability rate is shown in Table 4.

As displayed in Table 4, the composite reliability rate is more than 0.7 . Therefore, 
Table 1

Factor loading rate

\begin{tabular}{|c|c|c|c|c|c|}
\hline \multirow{2}{*}{ Indicator } & \multicolumn{4}{|c|}{ Factor Loading Rate of Indicator of Latent Variable } & \multirow{2}{*}{$\begin{array}{c}\text { Convergent } \\
\text { Validity }\end{array}$} \\
\hline & MO & TO & $\mathbf{E}$ & EO & \\
\hline MO1 & 0.756 & & & & Valid \\
\hline $\mathrm{MO} 2$ & 0.776 & & & & Valid \\
\hline MO3 & 0.864 & & & & Valid \\
\hline MO4 & 0.953 & & & & Valid \\
\hline MO5 & 0.850 & & & & Valid \\
\hline MO6 & 0.859 & & & & Valid \\
\hline TO1 & & 1.000 & & & Valid \\
\hline E1 & & & 1.000 & & Valid \\
\hline $\mathrm{EO} 2$ & & & & 0.831 & Valid \\
\hline EO4 & & & & 0.708 & Valid \\
\hline EO5 & & & & 0.760 & Valid \\
\hline
\end{tabular}

Table 2

AVE rate

\begin{tabular}{lcc}
\hline Latent Variable & AVE & Convergent Validity \\
\hline MO & 0.715 & Valid \\
TO & 1.000 & Valid \\
E & 1.000 & Valid \\
EO & 0.590 & Valid \\
\hline
\end{tabular}

Table 3

Cross loading rate

\begin{tabular}{lcccccc}
\hline \multirow{2}{*}{ Indicator } & \multicolumn{9}{c}{ Cross Loading Rate of Indicator on Latent } & $\begin{array}{l}\text { The Highest Cross } \\
\text { Variable }\end{array}$ & $\begin{array}{l}\text { Discriminant } \\
\text { Voading Rate }\end{array}$ & Validity \\
\cline { 2 - 5 } & MO & TO & E & EO & MO1 $\rightarrow$ MO & Valid \\
MO1 & 0.756 & 0.631 & 0.485 & 0.594 & MO & Valid \\
MO2 & 0.776 & 0.674 & 0.517 & 0.696 & MO2 $\rightarrow$ MO & Valid \\
MO3 & 0.864 & 0.698 & 0.583 & 0.748 & MO3 $\rightarrow$ MO & Valid \\
MO4 & 0.953 & 0.808 & 0.681 & 0.803 & MO4 $\rightarrow$ MO & Valid \\
MO5 & 0.850 & 0.687 & 0.587 & 0.735 & MO5 $\rightarrow$ MO & Valid \\
MO6 & 0.859 & 0.705 & 0.576 & 0.689 & MO6 $\rightarrow$ MO & Valid \\
TO1 & 0.831 & 1.000 & 0.694 & 0.680 & TO1 $\rightarrow$ TO & Valid \\
E1 & 0.680 & 0.694 & 1.000 & 0.645 & E1 $\rightarrow$ E & Valid \\
EO2 & 0.681 & 0.596 & 0.480 & 0.831 & EO2 $\rightarrow$ EO & Valid \\
EO4 & 0.547 & 0.563 & 0.471 & 0.708 & EO4 $\rightarrow$ EO & Valid \\
EO5 & 0.705 & 0.606 & 0.533 & 0.760 & EO5 $\rightarrow$ EO &
\end{tabular}

Note: Result of Analysis with SmartPLS at a significance level of 5\% 
Table 4

Composite reliability rate

\begin{tabular}{lcc}
\hline Latent Variable & Composite Reliability & Reliability \\
\hline MO & 0.937 & Reliable \\
TO & 1.000 & Reliable \\
E & 1.000 & Reliable \\
EO & 0.811 & Reliable \\
\hline
\end{tabular}

the model is considered reliable. Based on items presented in Tables 1-4, and referring to the principle of Hair et al. (2014), therefore, it can be said that the outer model is considered fit.

\section{Goodness-of-Fit Test on Inner Model}

The goodness-of-fit test on the inner model is done by evaluating the $\mathrm{R}^{2}$ value. Table 5 describes the $\mathrm{R}^{2}$ value of the inner model.

Table 5

$R^{2}$ value

\begin{tabular}{lll}
\hline $\begin{array}{l}\text { Endogenous } \\
\text { Latent Variable }\end{array}$ & $\mathrm{R}^{2}$ & Decision \\
\hline EO & 0.732 & $\begin{array}{l}\text { Inner Model is } \\
\text { Good }\end{array}$ \\
\hline
\end{tabular}

Pursuant to Table 5, the value of $\mathrm{R}^{2}$ is more than 0.25 . In accordance with the principle stated by Hair et al. (2014), therefore, the inner model is considered fit. The summary of the goodness-of-fit test result is shown in Table 6 .

As indicated in Table 6, the criteria of goodness-of-fit are fulfilled, and therefore, there is goodness-of-fit for the outer model (Hair et al., 2014) and goodness-of-fit for the inner model as well (Hair et al., 2014). Given this result, the research model is then perceived as fit and thus, can be used in the hypothesis test.

For direct effect hypotheses, the author conducted the hypothesis test by processing values derived from the bootstrapping

Table 6

Summary of the goodness-of-fit test result

\begin{tabular}{|c|c|c|c|c|}
\hline \multicolumn{2}{|c|}{ Goodness-of-Fit } & \multirow{2}{*}{$\begin{array}{l}\text { Parameter } \\
\text { Factor Loading }\end{array}$} & \multirow{2}{*}{$\begin{array}{l}\text { Rule of Thumb } \\
\text { Factor loading of all indicators } \\
\text { must be }>0.7\end{array}$} & \multirow{3}{*}{$\begin{array}{l}\text { Decision } \\
\text { Convergent } \\
\text { Validity Fulfilled }\end{array}$} \\
\hline \multirow[t]{4}{*}{$\begin{array}{l}\text { Outer } \\
\text { Model }\end{array}$} & \multirow[t]{2}{*}{$\begin{array}{l}\text { Convergent } \\
\text { Validity }\end{array}$} & & & \\
\hline & & AVE & $\begin{array}{l}\text { AVE of all indicators must be }> \\
0.5\end{array}$ & \\
\hline & $\begin{array}{l}\text { Discriminant } \\
\text { Validity }\end{array}$ & Cross Loading & $\begin{array}{l}\text { The factor loading of all indicators } \\
\text { in one latent variable must be } \\
\text { greater than those in other latent } \\
\text { variables. }\end{array}$ & $\begin{array}{l}\text { Discriminant } \\
\text { Validity Fulfilled }\end{array}$ \\
\hline & Reliability & $\begin{array}{l}\text { Composite } \\
\text { Reliability }\end{array}$ & $\begin{array}{l}\text { Composite Reliability must be }> \\
0.7\end{array}$ & Reliable \\
\hline $\begin{array}{l}\text { Inner } \\
\text { Model }\end{array}$ & $\mathrm{R}^{2}$ Evaluation & $\mathrm{R}^{2}$ Value & $\mathrm{R}^{2}>0.25$ & $\begin{array}{l}\text { Model considered } \\
\text { as fit }\end{array}$ \\
\hline
\end{tabular}


formula. The processing was done with Smart PLS 3.2.7. Alternative Hypothesis (Ha) is accepted only if $t_{\text {count }}$ is $\geq 1.96$ (Hair et al., 2014). The t-statistic ( $\left.t_{\text {count }}\right)$ values of the direct effect test are summarized in Table 7.

The hypothesis test on the direct effect relationship (Table 7) had given two results: (1) MO had a direct and significant effect on EO; and (2) TO had a direct and significant effect on EO. Baron and Kenny's Norm (Hair et al., 2014) required that the moderation effect could only be tested if the direct effect was proven to be significant. Related to the results in Table 7, where all direct effect relationships are significant, the moderation test is allowed to be conducted on the moderation relationships, such as:
(1) moderation effect of $E$ to the effect of MO on EO; and (2) moderation effect of $E$ to the effect of TO on EO. For these moderations (indirect effect) hypotheses, the testing process remained similar to that of the direct effect test. The similarity is in the use of Smart PLS 3.2.7 to process the values obtained from bootstrapping formulation. The summary of t-statistic ( $\left.\mathrm{t}_{\text {count }}\right)$ values from the moderation effect test is displayed in Table 8.

The summary of the factor loading, path coefficient, and t-statistic $\left(t_{\text {count }}\right)$ values shown in the hypothesis model is indicated in Figure 3.

Each result of the hypothesis test, as indicated in Figure 3, will be explained in separate sections.

Table 7

Summary of $t_{\text {count }}$ values from direct effect test

\begin{tabular}{|c|c|c|c|c|c|c|c|}
\hline \multirow{2}{*}{ No } & \multirow{2}{*}{ Direct Effect } & \multicolumn{2}{|c|}{ Hypothesis } & \multirow{2}{*}{$\begin{array}{l}\text { Path } \\
\text { Coeff. }\end{array}$} & \multirow{2}{*}{$\mathrm{t}_{\text {count }}$} & \multirow{2}{*}{ Decision } & \multirow{2}{*}{ Remark } \\
\hline & & $\mathrm{H}_{0}$ & $\mathrm{H}_{\mathrm{a}}$ & & & & \\
\hline 1. & $\begin{array}{l}\mathrm{MO} \text { on } \mathrm{EO} \\
(\mathrm{MO} \rightarrow \mathrm{EO})\end{array}$ & $\begin{array}{l}\mathrm{H}_{0(1)}: \\
\gamma_{11}=0\end{array}$ & $\begin{array}{l}\mathrm{H}_{\mathrm{a}(1)}: \gamma_{11} \\
\neq 0\end{array}$ & 0.596 & 5.942 & $\begin{array}{l}\mathrm{H}_{0} \text { is rejected; } \\
\mathrm{H}_{\mathrm{a}} \text { is accepted. }\end{array}$ & $\begin{array}{l}\text { The effect is } \\
\text { positive and } \\
\text { significant. }\end{array}$ \\
\hline 2. & $\begin{array}{l}\text { TO on EO } \\
(\mathrm{TO} \rightarrow \mathrm{EO})\end{array}$ & $\begin{array}{l}\mathrm{H}_{0(3)}: \gamma_{12} \\
=0\end{array}$ & $\begin{array}{l}\mathrm{H}_{\mathrm{a}(3)}: \gamma_{12} \\
\neq 0\end{array}$ & 0.191 & 2.162 & $\begin{array}{l}\mathrm{H}_{0} \text { is rejected; } \\
\mathrm{H}_{\mathrm{a}} \text { is accepted. }\end{array}$ & $\begin{array}{l}\text { The effect is } \\
\text { positive and } \\
\text { significant. }\end{array}$ \\
\hline
\end{tabular}

Table 8

Summary of $t_{\text {count }}$ values from moderation effect test

\begin{tabular}{|c|c|c|c|c|c|c|c|}
\hline \multirow{2}{*}{ No } & \multirow{2}{*}{$\begin{array}{c}\text { Moderation } \\
\text { (Indirect) Effect }\end{array}$} & \multicolumn{2}{|c|}{ Hypothesis } & \multirow{2}{*}{$\begin{array}{l}\text { Path } \\
\text { Coeff. }\end{array}$} & \multirow{2}{*}{$\mathrm{t}_{\text {count }}$} & \multirow{2}{*}{ Decision } & \multirow{2}{*}{ Remark } \\
\hline & & $\mathrm{H}_{0}$ & $\mathrm{H}_{\mathrm{a}}$ & & & & \\
\hline 1. & $\begin{array}{l}\mathrm{MO} \text { on } \mathrm{EO} \\
\text { moderated by } \mathrm{E} \\
(\mathrm{MO} * \mathrm{E} \rightarrow \mathrm{EO})\end{array}$ & $\begin{array}{l}\mathrm{H}_{0(2)}: \\
\gamma_{11}=0\end{array}$ & $\begin{array}{l}\mathrm{H}_{\mathrm{a}(2)}: \gamma_{11} \\
\neq 0\end{array}$ & -0.092 & 0.691 & $\begin{array}{l}\mathrm{H}_{0} \text { is } \\
\text { rejected, } \mathrm{H}_{\mathrm{a}} \text { is } \\
\text { accepted. }\end{array}$ & $\begin{array}{l}\text { The effect is } \\
\text { negative, but } \\
\text { not significant }\end{array}$ \\
\hline 2. & $\begin{array}{l}\mathrm{TO} \text { on } \mathrm{EO} \\
\text { moderated by } \mathrm{E} \\
\left(\mathrm{TO}{ }^{*} \mathrm{E} \rightarrow \mathrm{EO}\right)\end{array}$ & $\begin{array}{l}\mathrm{H}_{0(4)}: \gamma_{12} \\
=0\end{array}$ & $\begin{array}{l}\mathrm{H}_{\mathrm{a}(4)}: \gamma_{12} \\
\neq 0\end{array}$ & 0.047 & 0.454 & $\begin{array}{l}\mathrm{H}_{0} \text { is } \\
\text { rejected, } \mathrm{H}_{\mathrm{a}} \text { is } \\
\text { accepted. }\end{array}$ & $\begin{array}{l}\text { The effect is } \\
\text { not negative, } \\
\text { and also not } \\
\text { significant }\end{array}$ \\
\hline
\end{tabular}

Source: Result of analysis with SmartPLS at a significance level of 5\% 


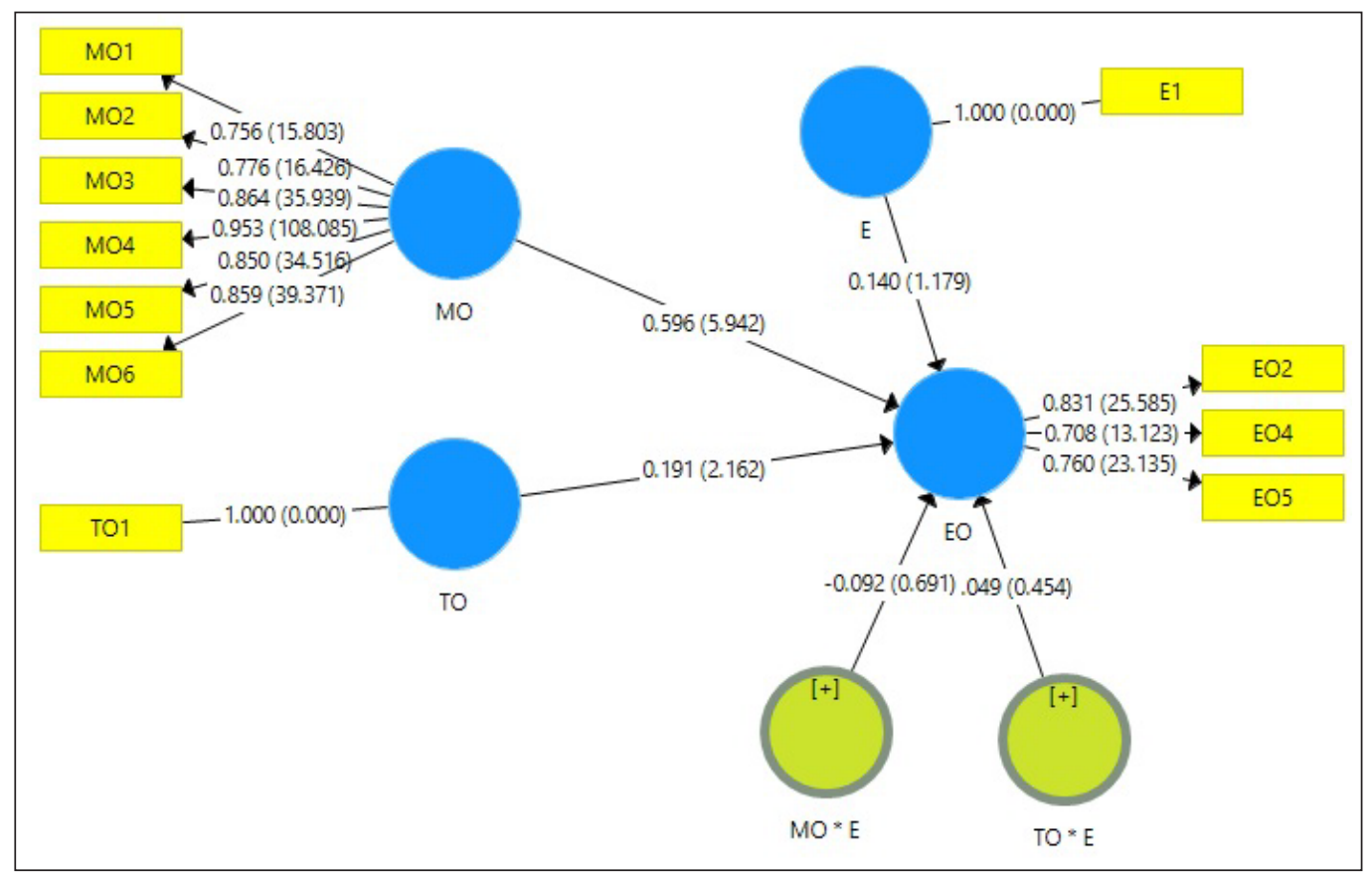

Figure 3. Summary of hypothesis model calculation results

Source: Result of analysis with SmartPLS at a significance level of 5\%

\section{Effect of Market Orientation on Entrepreneurship Orientation}

Market orientation of Small-and-Medium Enterprises in East Java has a positive and significant effect on entrepreneurship orientation. In other words, market orientation significantly increases entrepreneurship orientation.

Whether Small-and-Medium Enterprises are still active in the market depends on how they grow and compete with others in fulfilling market demand (Frishammar \& Hörte, 2007). Small-andMedium Enterprises may survive in the business competition if they have the capability to translate properly their market demand and strategic orientation (Acosta et al., 2018). Small-and-Medium Enterprises with market orientation should have better performance because they respect and apply entrepreneurship values such as innovation, risk-taking, and being aggressive in competing for market shares (Jangl, 2015). Indeed, Small-and-Medium Enterprises with entrepreneurship orientation do always need market orientation to effectively drive their innovative action on target markets (Amin et al., 2016). Pursuant to these statements, it can be said that Small-andMedium Enterprises' entrepreneurship orientation increases after they apply market orientation.

\section{Effect of Technology Orientation on Entrepreneurship Orientation}

The technology orientation of Smalland-Medium Enterprises in East Java has a positive and significant effect on 
entrepreneurship orientation. As the results showed, technology orientation increased entrepreneurship orientation.

Technology orientation is a key factor for the success of Small-and-Medium Enterprises (Zhai et al., 2018). The job environment has been affected by the fast growth of technology, and therefore, both values and effects of technology become apparent during the presentation of new products (Ali et al., 2016). The use of new technology needs to be supported by entrepreneurship values, such as innovation and that of being proactive in applying business strategy (Zhai et al., 2018). In other words, the SMEs' entrepreneurship orientation can be increased by improving technology orientation.

\section{Moderation Effect of Education in the Relationship of Market Orientation on Entrepreneurship Orientation}

Education acts as a moderator variable in the relationship of market orientation on entrepreneurship orientation. Education reduces the effect size of this relationship, but the level of this reduction is not significant statistically. There are two immediate causes for this situation. First is the low level of market orientation among Smalland-Medium Enterprises in East Java. Second is the low level of education among SMEs' workers which has prevented them from applying entrepreneurship values. Indeed, the further consequence of both low situations is the less optimality of entrepreneurship orientation.

Small-and-Medium Enterprises with entrepreneurship orientation are usually good at responding to market demands. Their market orientation tends to be responsive and proactive. The marketing strategy of SMEs, thus, always involves the exercise of market orientation supported by entrepreneurship values (Amin et al., 2016). If SMEs do have a good strategy and it is successfully executed, then it should improve performance (Acosta et al., 2018), especially when they innovate to empower market orientation.

The capability of being innovative and exercising other aspects of entrepreneurship is determined by knowledge, and regarding this matter, education can be an impelling factor that enforces entrepreneurship orientation. Education is a factor that determines the success of Small-andMedium Enterprises (Nawawi et al., 2017). The strength of market orientation depends on the capacity of SMEs to understand market situations, and the effective use of knowledge may help them to sell their newly created innovative products (John et al., 2016). Within the context of East Java, the education level of the majority of SME workers is not very high, and most of them only graduated from high schools. Organizational learning at SMEs in East Java is only apparent among managers and secretaries (Al Idrus et al., 2018). This limited learning scope results in less optimality on the application of market orientation and entrepreneurship values because almost none of the lower-level workers has enough knowledge about entrepreneurship, and this surely will affect the SMEs' road to success. 
Moderation Effect of Education in the Relationship of Technology Orientation on Entrepreneurship Orientation

Education is a moderator variable in the relationship of technology orientation on entrepreneurship orientation. In this situation, education increases the relationship of technology orientation on entrepreneurship orientation, and its moderation effect is not significant statistically. The reason is that the technology currently used by Smalland-Medium Enterprises in East Java is less up-to-date. As a result, the workers of these SMEs always find it difficult to apply entrepreneurship values such as innovation and lack of enthusiasm to learn new things. The majority of SME workers have low education levels and therefore, they will have difficulty in benefiting from the use of new technology.

To develop new products, Small-andMedium Enterprises always need sustainable capabilities and should work to improve on innovation and also to adjust its production lines to provide room for the adoption of recent technology (Kamal et al., 2016). Small-and-Medium Enterprises must predict the growth of technology and keep track of it in order to make technology usable in their products and production process. This predicting capacity and the skill of using current technology should help SMEs to improve their business performance (Ali et al., 2016). In other words, a high level of technology orientation can affect the entrepreneurship orientation of Smalland-Medium Enterprises. However, they must still embrace education to develop individuals with skills and capabilities relevant to the use of current technology. Human resource is one of the determining factors for the success of SMEs, especially when workers are capable of using current technology. Workers with high education find it easier to adapt to new technology (Carruth \& Carruth, 2013), and this knowledge of technology helps them to be more innovative.

\section{CONCLUSION}

It can be concluded that the market orientation of Small-and-Medium Enterprises (SMEs) in East Java can significantly increase their entrepreneurship orientation. Market orientation and entrepreneurship orientation are strategies that enable SMEs to increase their business growth (Miles \& Arnold, 1991). If the business carried out by SMEs is not oriented to market tastes, there would be a mismatch between demand and supply in the market. The compatibility between SMEs and the market can be realized by ensuring that the capital structure and the marketing system of SMEs are running well. But, it must be noted that it always becomes a problem if there is no solid base that can be used by SMEs to satisfy market desires. The education level can reduce the effect of market orientation on entrepreneurship orientation of SMEs in East Java, but the reduction is not statistically significant as revealed in this study. In the era of globalization, entrepreneurship orientation does not only rely on the level of education but also involves experience, emotional intelligence, organization, and analysis of 
consumer behavior, because all of these are considered as a necessity, especially when it involves competition (Yaghoubi \& Naroei, 2011). Also, education levels can increase the effect of technology orientation on the entrepreneurship orientation of SMEs in East Java. However, in this study, the increase is not statistically significant. The effect of technology orientation on entrepreneurship orientation is not actually intended to facilitate operations but to help entrepreneurs in deciding production outputs. The use of technology must still involve innovation in marketing in order to improve performance. Despite the importance of this innovation, however, education cannot guarantee the implementation of innovation because educational institutions in current days are often designing curricula that are oriented more to office jobs rather than to entrepreneurship (Bae et al., 2014; Kunday \& Çakir, 2014; Saqib et al., 2018).

This research provides input and considerations concerning the moderation effect of education on the effect of market orientation and technology orientation on entrepreneurship orientation among Small-and-Medium Enterprises. The suggestion is that market orientation should be increased by intensifying the variation of the market's supply and demand and by enhancing marketing targets. Technology orientation must be improved by upgrading the technology currently used by Smalland-Medium Enterprises. This upgrading process can be achieved by giving employees training on recent technology. The education level of human resources at
Small-and-Medium Enterprises can also be improved by hiring candidates who have adequate educational backgrounds and then providing them with on-the-job training to increase their knowledge about the expected performance, the latest technology, and the importance of market orientation.

\section{ACKNOWLEDGEMENTS}

Many thanks to colleagues for their suggestions to improve the quality of this article.

\section{REFERENCES}

Abdilahi, M. H., \& Hassan, A. A. (2017). The impact of innovation on small and medium enterprises performance : Empirical evidence from Hargeisa, Somaliland. International Journal of Academic Research in Business and Social Sciences, 7(8), 14-28. https://doi.org/10.6007/IJARBSS/ v7-i8/3202

Acar, A. Z., \& Özşahin, M. (2017). The relationship among strategic orientations, organizational innovativeness, and business performance. International Journal of Innovation Management, 22(01), 1850009. https://doi.org/10.1142/ s1363919618500093

Acosta, A. S., Crespo, Á. H., \& Agudo, J. C. (2018). Effect of market orientation, network capability and entrepreneurial orientation on international performance of small and medium enterprises (SMEs). International Business Review, 27(6), 1128-1140. https://doi.org/10.1016/j. ibusrev.2018.04.004

Aksoy, H. (2017). How do innovation culture, marketing innovation and product innovation affect the market performance of small and medium-sized enterprises (SMEs)? Technology in Society, 51, 133--141. https://doi.org/10.1016/j. techsoc.2017.08.005 
Al Asheq, A., \& Hossain, M. U. (2019). SME Performance: Impact of market, customer and brand orientation. Academy of Marketing Studies Journal, 23(1), 1-9.

Al Idrus, S., Ahmar, A. S., \& Abdussakir. (2018). The effect of organizational learning on market orientation moderated by job satisfaction. Cogent Business and Management, 5(1), 1-12. https:// doi.org/10.1080/23311975.2018.1475048

Ali, R., Leifu, \& Rehman, R. (2016). The impact of technology orientation and customer orientation on firm performance: evidence from Chinese firms. International Journal of Management and Marketing Research, 9(1), 1-11.

Amfo, P., Cudjoe, G., Acheampong, G., Adams, M., \& Boakye, E. (2018). Market orientation, innovation and business performance: Insight from womenpreneurs in the fashion industry in Ghana. Journal of Creativity and Business Innovation, 4, 5-27.

Amin, M., Thurasamy, R., Aldakhil, A. M., \& Kaswuri, A. H. (2016). The effect of market orientation as a mediating variable in the relationship between entrepreneurial orientation and SMEs performance. Nankai Business Review International, 7(1), 39-59. https://doi. org/10.1108/NBRI-08-2015-0019

Anton, S. A., Muzakan, I., \& Muhammad, W. F. (2015). An assessment of SME competitiveness in Indonesia. Journal of Competitiveness, 7(2), 60-74. https://doi.org/10.7441/joc.2015.02.04

Asim, Z., \& Sorooshian, S. (2019). Exploring the role of knowledge, innovation and technology management (KNIT) capabilities that influence research and development. Journal of Open Innovation: Technology, Market, and Complexity, 5(21), 1-47. https://doi.org/10.3390/ joitmc5020021

Astutie, Y. P., \& Fanani, B. (2016). Small to mediumsized enterprises and their financial report quality. International Journal of Economics and Financial Issues, 6(S4), 36-45.

Bae, T. J., Qian, S., Miao, C., \& Fiet, J. O. (2014). The relationship between entrepreneurship education and entrepreneurial intentions: A metaanalytic review. Entrepreneurship: Theory and Practice, 38(2), 217-254. https://doi.org/10.1111/ etap. 12095

Becker, J.-M., Ringle, C. M., \& Sarstedt, M. (2018). Estimating moderating effect in PLS-SEM and PLSc-SEM: Interaction term generation*data treatment. Journal of Applied Structural Equation Modeling, 2(2), 1-21.

Berrill, J., O’Hagan-Luff, M., \& van Stel, A. (2018). The moderating role of education in the relationship between FDI and entrepreneurial activity. Small Business Economics, 54(4), 1041-1059. https://doi.org/10.1007/s11187018-0121-6

Bosma, N., \& Schutjens, V. (2011). Understanding regional variation in entrepreneurial activity and entrepreneurial attitude in Europe. Annals of Regional Science, 47(3), 711-742. https://doi. org/10.1007/s00168-010-0375-7

Buana, Y., Hidayat, D., Prayogi, B., \& Vendy, V. (2017). The effect of entrepreneurship education on entrepreneurial intention of university students by adopting Linan model. Binus Business Review, 8(1), 67-75. https://doi. org/10.21512/bbr.v8i1.1958

Carruth, P. J., \& Carruth, A. K. (2013). Educational and financial impact of technology on workforce development. American Journal of Business Education, 6(5), 513-520. doi:10.19030/ajbe. v6i5.8041

Charupongsopon, W., \& Puriwat, W. (2017). The influence of entrepreneurial orientation and family business's resources and capabilities on marketing performances. European Research Studies Journal, XX(2A), 150-163. doi:10.35808/ ersj/634 
Chienwattanasook, K., \& Jermsittiparsert, K. (2019). Impact of entrepreneur education on entrepreneurial self-employment: A study from Thailand. Polish Journal of Management Studies, 19(1), 106-116. https://doi.org/10.17512/ pjms.2019.19.1.08

Danakol, S. H., Estrin, S., Reynolds, P., \& Weitzel, U. (2017). Foreign direct investment via M\&A and domestic entrepreneurship: Blessing or curse? Small Business Economics, 48(3), 599-612. https://doi.org/10.1007/s11187-016-9792-z

Diaw, B., \& Asare, G. (2018). Effect of innovation on customer satisfaction and customer retention in the telecommunication industry in Ghana: Customers' perspectives. European Journal of Research and Reflection in Management Sciences, 6(4), 15-26.

Dursun, T., \& Kilic, C. (2017). Conceptualization and measurement of market orientation: A review with a roadmap for future research. International Journal of Business and Management, 12(3), 1-18. doi:10.5539/ijbm.v12n3p1

Entrialgo, M., \& Iglesias, V. (2016). The moderating role of entrepreneurship education on the antecedents of entrepreneurial intention. International Entrepreneurship and Management Journal, 12(4), 1209-1232. https://doi. org/10.1007/s11365-016-0389-4

Ertuna, Z. I., \& Gurel, E. (2011). The moderating role of higher education on entrepreneurship. Education and Training, 53(5), 387-402. https:// doi.org/10.1108/00400911111147703

Fayolle, A., \& Gailly, B. (2015). The impact of entrepreneurship education on entrepreneurial attitudes and intention: Hysteresis and persistence. Journal of Small Business Management, 53(1), 75-93. https://doi.org/10.1111/jsbm.12065

Frishammar, J., \& Hörte, S. Å. (2007). The role of market orientation and entrepreneurial orientation for new product development performance in manufacturing firms. Technology Analysis \& Strategic Management Management, 19(6), 765-788. https://doi. org/10.1080/09537320701711231

Hadiyati, E. (2015). Marketing and government policy on MSMEs in Indonesian: A theoretical framework and empirical study. International Journal of Business and Management, 10(2), 128-141. doi:10.5539/ijbm.v10n2p128

Hair, J. F., Hult, G. T. M., Ringle, C. M., \& Sarstedt, M. (2014). A primer on partial least squares structural equation modeling (PLS-SEM). California: SAGE Publications, Inc.

Haliq, I., Pambudy, R., \& Alfikri, S. (2018). Influence of entrepreneurship orientation on business performance of broiler husbandry in the partnership and the independent scheme in Bogor. International Journal of Agriculture System, 6(1), 25-34. https://doi.org/10.20956/ ijas.v6i1.1252

Heslina, Payangan, O. R., Taba, M. I., \& Pabo, M. I. (2016). Factors affecting the business performance of the micro, small and medium enterprises in creative economic sector in Makassar, Indonesia. Scientific Research Journal, IV(I), 41-49.

Hidayat, C., Suryana, Y., Afiff, F., \& Cahyandito, M. F. (2016). The relationship of entrepreneurial and market orientation, marketing mix, and business performance. International Journal of Economics, Commerce and Management, IV(9), 611-622.

Hinson, R. E., Abdul-Hamid, I. K., \& Osabutey, E. L. C. (2017). Investigating market orientation and positioning in star-rated hotels in Ghana. International Journal of Contemporary Hospitality Management, 29(10), 2629-2646. https://doi.org/10.1108/IJCHM-02-2016-0075

Hussain, J., Rahman, W., \& Shah, F. A. (2016). Market orientation and performance: The interaction 
effect of entrepreneurial orientation. Pakistan Journal of Commerce and Social Sciences, 10(2), 388-403.

Ibrahim, M. I., Keat, O. Y., \& Rani, S. H. B. A. (2017). Entrepreneurial orientation, technology orientation and small and medium enterprises performance in Nigeria: Role of government support policies. Journal of Business and Social Review in Emerging Economies, 3(1), 75-84. doi:10.26710/jbsee.v3i1.44

Ismail, M. D., \& Alam, S. S. (2019). Innovativeness and competitive advantage among small and medium enterprise exporters: Evidence from emerging markets in South East Asia. The South East Asian Journal of Management, 13(1), 7491. doi:10.21002/seam.v13i1.9872

Ismanu, S., \& Kusmintarti, A. (2019). Innovation and firm performance of small and medium enterprises. Review of Integrative Business and Economics Research, 8(2), 312-323.

Jang1, P. (2015). Relationship between market orientation and business performance in Czech and German high-tech firms. Market-Tržište, 27(2), 153-170.

John, E., Bueno, G., Lyra, F. R., \& Lenzi, F. C. (2016). Knowledge management, market orientation and innovation: A study at a Technology Park of Santa Catarina. Brazilian Business Review, 13(3), 70-89. https://doi.org/http://dx.doi. org/10.15728/bbr.2016.13.3.4

Kamal, S. B. M., Zawawi, D., \& Abdullah, D. (2016). Entrepreneurial orientation for small and medium travel agencies in Malaysia. Procedia Economics and Finance, 37(16), 115-120. https://doi.org/10.1016/S2212-5671(16)30101-0

Khaleel, A. J., Al-shami, S. A., Majid, I., \& Adel, H. (2017). The effect of entrepreneurial orientation of small firms innovation. Journal of Technology Management and Technopreneurship, 5(1), 37-50.
Kunday, Ö., \& Çakir, C. (2014). The moderating role of entrepreneurship education and family tradition on the relationship between self-esteem and entrepreneurial intention. International Journal of Humanities and Social Science, 4(9), 25-34.

Ling, L. S. (2017). Impacts of information technology capabilities on small and medium enterprises (SMEs) and large enterprises. Journal of Innovation Management in Small \& Medium Enterprises, 2017(2017), 1-9. https://doi. org/10.5171/2017.133143

Lo, M. C., Wang, Y. C., Wah, C. R. J., \& Ramayah, T. (2016). The critical success factors for organizational performance of SMEs in Malaysia: A partial least squares approach. Review of Business Management, 18(61), 370391. doi:10.7819/rbgn.v18i61.3058

Madu, I. (2016). Production techniques and technological orientation on the performance of manufacturing industries in Nigeria. International Business and Management, 13(1), 29-35. https://doi.org/10.3968/8745

Miles, M. P., \& Arnold, D. R. (1991). The relationship between marketing orientation and entrepreneurial orientation. Entrepreneurship Theory and Practice, 15(4), 49-66. https://doi. org/10.1177/104225879101500407

Mugambi, E. N., \& Karugu, W. N. (2017). Effect of entrepreneurial marketing on performance of real estate enterprises: A case of optiven limited in Nairobi, Kenya. International Academic Journal of Innovation, Leadership and Entrepreneurship, 2(1), 26-45.

Munizu, M., Sumardi, S., \& Armayah, A. (2016). Study on determinant factors of micro and small enterprises development in South Sulawesi of Indonesia. Mediterranean Journal of Social Sciences, 7(6), 121-128. https://doi.org/10.5901/ mjss.2016.v7n6p121 
Mutlutürk, M. (2018). Analysing factors affecting the individual entrepreneurial orientation of university students. Journal of Entrepreneurship Education, 21(1S), 1-15.

Na, Y. K., Kang, S., \& Jeong, H. Y. (2019). The effect of market orientation on performance of sharing economy business: Focusing on marketing innovation and sustainable competitive advantage. Sustainability (Switzerland), 11(3), 1-19. https://doi.org/10.3390/su11030729

Nabi, G., Walmsley, A., \& Holden, R. (2015). Pushed or pulled? Exploring the factors underpinning graduate start-ups and non-start-ups. Journal of Education and Work, 28(5), 481-506. https://doi. org/10.1080/13639080.2013.805189

Nabi, G., Linan, F., Fayolle, A., Krueger, N., \& Walmsley, A. (2017). The impact of entrepreneurship education in higher education: A systematic review and research agenda. Academy of Management Learning \& Education, 16(2), 277-299.

Nawawi, T., Husin, R., \& Wiryawan, Z. Z. (2017). Profile and marketing strategy of SME's towards Jambi batik. Business and Economics Journal, 8(4), 1-6. doi:10.4172/2151-6219.1000334

Nga, J. K. H., \& Shamuganathan, G. (2010). The influence of personality traits and demographic factors on social entrepreneurship start up intentions. Journal of Business Ethics, 95(2), 259-282. https://doi.org/10.1007/s10551-0090358-8

Nwachukwu, C., Chladkova, H., \& Zuvan, P. (2017). The relationship between entrepreneurial orientation, entrepreneurial competencies, entrepreneurial leaderhip, and firm performance: A proposed model. Business Trends, 7(1), 3-16.

Obeidat, B. Y. (2016). The effect of strategic orientation on organizational performance: the mediating role of innovation. International Journal of Communications, Network and
System Sciences, 9(11), 478-505. https://doi. org/10.4236/ijcns.2016.911039

Octavia, A., \& Ali, H. (2017). The model of market orientation, entrepreneurial orientation and business performance of small and medium enterprises. International Review of Management and Marketing, 7(3), 331-337.

Oluwatoyin, A. M., Olufunke, A. P., \& Salome, I. O. (2018). The impact of market orientation on performance of selected hotels in Ondo State, Nigeria. Open Journal of Business and Management, 6(3), 616-631. https://doi. org/10.4236/ojbm.2018.63047

Omar, C. M. Z. C., \& Anas, T. (2014). The marketing of small and medium enterprise (SME) products based on food processing. European Journal of Business and Social Sciences, 3(5), 76-87.

Oni, O., Agbobli, E. K., \& Iwu, C. G. (2019). Entrepreneurial orientation and performance of small business in Vryburg Region North West Province South Africa. Journal of Reviews on Global Economics, 8, 63-71. https://doi. org/10.6000/1929-7092.2019.08.07

Patricia, P., \& Silangen, C. (2016). The effect of entrepreneurship education on entrepreneurial intention in Indonesia. DeReMa (Development Research of Management): Jurnal Manajemen, 11(1), 67-86. doi:10.19166/derema.v11i1.184

Peterman, N. E., \& Kennedy, J. (2003). Enterprise education: Influencing students' perceptions of entrepreneurship. Entrepreneurship Theory and Practice, 28(2), 129-144. https://doi. org/10.1046/j.1540-6520.2003.00035.x

Pett, T., \& Wolff, J. A. (2016). Entrepreneurial orientation and learning in high and lowperforming SMEs. Journal of Small Business Strategy, 26(2), 71-86.

Piperopoulos, P., \& Dimov, D. (2015). Burst bubbles or build steam? Entrepreneurship 
education, entrepreneurial self-efficacy, and entrepreneurial intentions. Journal of Small Business Management, 53(4), 970-985. https:// doi.org/10.1111/jsbm.12116

Pustovrh, A., Jakliča, M., Martina, S. A., \& Raškovića, M. (2017). Antecedents and determinants of hightech SMEs' commercialisation enablers: Opening the black box of open innovation practices. Economic Research, 30(1), 1033-1056. https:// doi.org/10.1080/1331677X.2017.1305795

Rahyuda, A. G., Indrawati, A. D., Candraningrat, I. R., \& Satrya, I. G. B. H. (2017). Exploring entrepreneurs' exit strategies in Indonesian small and medium-sized enterprises. International Journal of Entrepreneurship, 21(2), 59-73.

Saqib, M., Zarine, R., \& Udin, Z. M. (2018). Exploring the technology orientation influence on the innovativeness-performance relationship of manufacturing SMEs. International Journal of Innovation and Learning, 24(3), 277-300. https:// doi.org/10.1504/IJIL.2018.094708

Sembiring, R. (2016). Impact of human resources' knowledge and skills on SMEs' in Medan City, Indonesia International. International Journal of Management, Economics and Social Sciences, 5(3), 95-104.

Shah, I. A., Amjed, S., \& Jaboob, S. (2020). The moderating role of entrepreneurship education in shaping entrepreneurial intentions. Journal of Economic Structures, 9(19), 1-15. https://doi. org/10.1186/s40008-020-00195-4

Souitaris, V., Zerbinati, S., \& Al-Laham, A. (2007). Do entrepreneurship programmes raise entrepreneurial intention of science and engineering students? The effect of learning, inspiration and resources. Journal of Business Venturing, 22(4), 566-591. https://doi. org/10.1016/j.jbusvent.2006.05.002
Tarighi, R., Sajjadi, S. N., Hamidi, M., \& Khabiri, M. (2017). Factors affecting the development of the electronic marketing capacity of professional sports federations. Annals of Applied Sport Science, 5(2), 87-96. https://doi.org/10.18869/ acadpub.aassjournal.5.2.87

Tseng, C. H., Chang, K. H., \& Chen, H. W. (2019). Strategic orientation, environmental innovation capability, and environmental sustainability performance: The case of Taiwanese suppliers. Sustainability (Switzerland), 11(4), 1-19. https:// doi.org/10.3390/su11041127

Ungerman, O., Dedkova, J., \& Gurinova, K. (2018). The impact of marketing innovation on the competitiveness of enterprises in the context of industry 4.0. Journal of Competitiveness, 10(2), 132-148. doi:10.7441/joc.2018.02.09

Wambugu, A. W., Gichira, R., Wanjau, K. N., \& Mung'atu, J. (2015). The relationship between risk taking and performance of small and medium agro processing enterprises in Kenya. International Journal of Economics, Commerce and Management, 3(12), 441-455.

Yaghoubi, N., \& Naroei, M. (2011). Affecting factors on entrepreneurial orientation in the industry. Chinese Business Review, 10(10), 889-894. https://doi.org/10.17265/1537-1506/2011.10.006

Yamane, T. (1967). Statistic: An introductory analysis (2nd ed.). New York, USA: Harper and Row.

Zhai, Y. M., Sun, W. Q., Tsai, S. B., Wang, Z., Zhao, Y., \& Chen, Q. (2018). An empirical study on entrepreneurial orientation, absorptive capacity, and SMEs' innovation performance: A sustainable perspective. Sustainability (Switzerland), 10(2), 1-14. https://doi.org/10.3390/su10020314 